\title{
Immunohistochemistry of cytokeratin proteins in squamous and transitional cell lesions of the urinary tract
}

\author{
M F TUNGEKAR, K C GATTER, * M S AL-ADNANI \\ From the Department of Pathology, Faculty of Medicine, Kuwait University, Kuwait, and the *Nuffield \\ Department of Pathology, John Radcliffe Hospital, Oxford
}

SUMMARY Expression of low and high molecular weight cytokeratin proteins was investigated immunohistochemically in a variety of transitional and squamous epithelial lesions of the urinary tract with and without schistosomiasis. The monoclonal antibodies used were CAM $5 \cdot 2$ and NCL5D3 for low, PK 63 and 121 for high, and MAK 6 for a broad range of intermediate molecular weight cytokeratins. On staining with CAM $5 \cdot 2$ and NCL5D3, urothelial hyperplasias $(n=12)$ and grades $1(n=5)$ and $2(n=10)$ papillary transitional cell carcinomas showed labelling patterns quite distinct from carcinoma in situ $(n=4)$ and non-papillary grades $2(n=6)$ and 3 tumours $(n=3)$. Among squamous lesions only focal positivity was obtained in 14 of 22 moderate to poorly differentiated squamous cell carcinomas. By contrast, PK 63 and 121 stained squamous lesions exclusively. MAK 6 stained the whole range of urothelial and squamous lesions with the exception of squamous metaplasias. Polyclonal antikeratin adequately labelled spindle cell areas of high grade tumours. The distinctive staining patterns given by these or similar antibodies may help in the identification of squamous metaplasia and in diagnosing tumours of the urothelium.

Over the past few years the biochemical and immunohistochemical studies of intermediate filament proteins have generated tremendous interest among cell biologists and pathologists. ${ }^{12}$ Of the five classes of intermediate filament, the cytokeratins which constitute the cytoskeleton of epithelia comprise a heterogeneous group of at least 19 multigene derived proteins, identifiable by two-dimensional gel electrophoresis and by monoclonal antibodies. ${ }^{3}$ Studies of these proteins in simple and stratified epithelia have shown different distribution patterns. ${ }^{24}$ Within the stratified epithelia, such as squamous and transitional (urothelial), the various cytokeratin proteins are differentially expressed in basal, intermediate, and superficial layers in their native and diseased states. ${ }^{5-7}$

The immunolocalisation of the cytokeratin proteins can therefore be used to determine the routes of differentiation of epithelial lesions. ${ }^{48-11}$ Recent reports of aberrant coexpression of other intermediate filaments along with cytokeratins by carcinomas of

Accepted for publication 11 July 1988 various sites $^{12-15}$ and the unexpected absence of some cytokeratin protein subclasses in some squamous cancers, however, ${ }^{14}{ }^{16}$ have indicated a possible heterogeneity among tumours of similar morphology at different sites.

Schistosomiasis of the urinary tract is often associated with various hyperplastic and neoplastic lesions of the squamous and transitional types. ${ }^{17}{ }^{18}$ In a preliminary study we showed that squamous cell carcinoma arising in such bladders inconsistently express low molecular weight cytokeratin proteins as identified by a murine monoclonal antibody CAM $5 \cdot 2 .^{19}$ This was in contrast to similar studies on similar cervical tumours. ${ }^{20}$

To evaluate our findings further we extended our immunohistochemical study to apply a wider panel of monoclonal antibodies against cytokeratin proteins of different molecular weights: as there have been no large studies of this nature comparing squamous and transitional cell lesions of the urinary tract, we included epithelial lesions of both types with and without schistosomiasis. Lymph node metastases of some of these tumours were also similarly studied. 
Table 1 Details of cases studied

\begin{tabular}{|c|c|c|c|}
\hline Lesion & Site & Number & With schistosomiasis \\
\hline $\begin{array}{l}\text { Urothelial lesions: } \\
\text { Hyperplasias } \\
\text { Carcinoma in situ } \\
\text { Transitional cell carcinoma grade } 1 \\
\text { Transitional cell carcinoma grade } 2 \\
\text { Transitional cell carcinoma grade } 3 \\
\text { Transitional cell carcinoma grade } 3\end{array}$ & $\begin{array}{l}\mathbf{B} \\
\mathbf{B} \\
\mathbf{B} \\
\mathbf{B} \\
\mathbf{B} \\
\mathbf{P}\end{array}$ & $\begin{array}{r}12 \\
4 \\
3 \\
16 \\
4 \\
1\end{array}$ & $\begin{array}{r}12 \\
0 \\
1 \\
4 \\
1 \\
0\end{array}$ \\
\hline $\begin{array}{l}\text { Squamous lesions: } \\
\text { Metaplasia } \\
\text { Carcinomas }\end{array}$ & B & 10 & 10 \\
\hline $\begin{array}{l}\text { Well differentiated } \\
\text { Moderately differentiated } \\
\text { Moderately differentiated } \\
\text { Poorly differentiated }\end{array}$ & $\begin{array}{l}\mathbf{B} \\
\mathbf{B} \\
\mathbf{P} \\
\mathbf{B}\end{array}$ & $\begin{array}{r}10 \\
12 \\
2 \\
6\end{array}$ & $\begin{array}{r}9 \\
11 \\
1 \\
6\end{array}$ \\
\hline $\begin{array}{l}\text { Spindle cell components in: } \\
\text { Transitional cell carcinoma grade } 3 \\
\text { Squamous cell carcinoma (poorly differentiated) }\end{array}$ & $\begin{array}{l}\mathbf{B} \\
\mathbf{B}\end{array}$ & $\begin{array}{l}3 \\
2\end{array}$ & $\begin{array}{l}0 \\
2\end{array}$ \\
\hline $\begin{array}{l}\text { Lymph node metastases from: } \\
\text { Transitional cell carcinoma } \\
\text { Squamous cell carcinoma }\end{array}$ & & $\begin{array}{l}2 \\
2\end{array}$ & \\
\hline
\end{tabular}

$\mathbf{B}=$ Bladder; $\mathbf{P}=$ Renal pelvis

\section{Material and methods}

The material for this study was obtained from the surgical pathology service of Mubarak Al-Kabeer teaching hospital, Kuwait and is summarised in table 1. The specimens were fixed in $10 \%$ buffered formalin and routinely processed. Conventionally stained sections were reviewed to classify the lesions ${ }^{21}$ and to select blocks for immunohistochemistry.

Trypsinised $5 \mu \mathrm{m}$ sections were used. The sources of primary antibodies and their specificities are indicated in table 2 . Indirect peroxidase or alkaline phosphatase-antialkaline phosphatase (APAAP) methods were used to visualise immunoreactivity: the latter was preferred where an excessive inflammatory component was present.

Appropriate tissues with known positive and negative reactivities were used as controls (table 2). Non-lesional adjacent urothelium also served as an internal control for most cases. In each run parallel sections incubated with non-immune sera instead of primary antibody were used as additional negative controls.

\section{Results}

The results of immunostaining are summarised in table 3. They are described here, independent of their sites and presence of schistosomiasis, as these factors had no important influence on staining patterns.

\section{TRANSITIONAL EPITHELIUM AND ITS LESIONS}

All the transitional epithelial lesions as well as the normal urothelium were uniformly stained with polyvalent anti-keratin and were negative with PK 63 and 121. The following account deals with the labelling patterns obtained by CAM 5.2, MAK 6, and NCL5D3.

In the normal urothelium CAM 5.2 and NCL5D3 principally labelled the most superficial layer of "dome" cells (fig la). MAK 6 also stained deeper layers albeit less strongly. Staining of hyperplastic transitional epithelium by these three antibodies was similar and displayed a "gradient" pattern, showing a stronger positivity in the superficial than the deeper cell layers (fig 1b).

In situ transitional cell carcinoma of the flat mucosa

Table 2 Primary antibodies, their specificities, controls used and sources

\begin{tabular}{|c|c|c|c|c|}
\hline \multirow[b]{2}{*}{ Antibody* } & \multirow{2}{*}{$\begin{array}{l}\text { Cytokeratin proteins identified } \\
\text { (molecular weights) }\end{array}$} & \multirow[b]{2}{*}{ Source } & \multicolumn{2}{|l|}{ Controls used } \\
\hline & & & Positive & Negative \\
\hline $\begin{array}{l}\text { CAM 5.2 } \\
\text { NCL } 5 D 3 \\
\text { MAK } 6 \\
\text { PK } 63 \\
\text { Polyvalent antikeratin }\end{array}$ & $\begin{array}{l}39,43,50 \mathrm{kd} \\
40,45,52 \mathrm{kd} \\
40,50,52,56 \mathrm{kd} \\
50 \text { to } 67 \mathrm{kd} \\
\text { Broad spectrum }\end{array}$ & $\begin{array}{l}\text { Becton Dickinson } \\
\text { Eurodiagnostics BV } \\
\text { Triton Biosciences } \\
\text { K Pulford } \\
\text { Dakopatts }\end{array}$ & $\begin{array}{l}\text { Breast, prostate } \\
\text { Breast, prostate } \\
\text { Breast, prostate } \\
\text { Adult epidermis } \\
\text { All epithelia }\end{array}$ & $\begin{array}{l}\text { Adult epidermis } \\
\text { Adult epidermis } \\
\text { Adult epidermis } \\
\text { Breast }\end{array}$ \\
\hline
\end{tabular}

*All antibodies are monoclonal except the polyvalent antikeratin 
Table 3 Summary of positive immunostaining

\begin{tabular}{lccc}
\hline Lesion & $\begin{array}{c}\text { CAM 5.2, } \\
\text { NCLSD3 }\end{array}$ & MAK 6 & $\begin{array}{l}\text { PK 63 } \\
\text { and 121 }\end{array}$ \\
\hline $\begin{array}{l}\text { Urothelial hyperplasias } \\
\text { Flat transitional cell }\end{array}$ & $12 / 12$ & $12 / 12$ & $0 / 12$ \\
$\begin{array}{l}\text { carcinoma in situ } \\
\text { Transitional cell carcinoma } \\
\text { (all grades) }\end{array}$ & $24 / 4$ & $4 / 4$ & $0 / 4$ \\
$\begin{array}{l}\text { Pure squamous metaplasia } \\
\text { Squamous cell carcinoma } \\
\text { (well differentiated) }\end{array}$ & $0 / 10$ & $24 / 24$ & $0 / 24$ \\
$\begin{array}{l}\text { (moderately } \\
\text { differentiated) }\end{array}$ & $0 / 10$ & $0 / 10$ & $10 / 10$ \\
$\begin{array}{l}\text { (poorly differentiated) } \\
\text { (coexistent with } \\
\text { transitional cell } \\
\text { carcinoma }\end{array}$ & $7 / 14$ & $14 / 14$ & $10 / 10$ \\
\hline
\end{tabular}

for the most part showed uniformly positive labelling of all layers by CAM 5.2, MAK 6, and NCL5D3 (fig 1a).

Papillary grade 1 transitional cell carcinoma displayed the "gradient" type of staining patterns similar to those seen in normal and hyperplastic urothelia (fig 1c). Among the 16 grade 2 tumours, 10 were entirely papillary and showed the "gradient" pattern while the rest (six cases) had an additional nonpapillary or "solid" component which displayed staining of all layers similar to the flat carcinomas in situ (fig 2). Tumours of grade 3 also showed uniform labelling of all cells.

\section{SQUAMOUS METAPLASIAS AND CARCINOMAS}

The control epidermis showed intense labelling of the suprabasal cells with PK 63 and 121 (fig 3a). CAM $5 \cdot 2$, NCL5D3, and MAK 6 did not label the control epidermis or any squamous metaplasias, whereas the polyvalent antikeratin serum stained all epithelial tissues.

The squamous metaplasia of the urothelium showed similar patterns of staining with PK 63 and 121. The reaction, however, was limited to more superficial layers (fig 3b). Even small foci of squamous metaplasia in transitional cell carcinoma were stained with varying intensity by PK 63 and 121 (fig 3c).

The labelling of squamous cell carcinoma with PK 63 and 121 was proportional to their differentiation: the most differentiated types (verrucous) showed intense staining of most cells (fig 3d); staining was confined more to the centres of cell groups in less differentiated tumours (fig 4a).

With CAM 5.2 and NCL5D3, positivity was seen only in the less differentiated tumours and only a minority of tumour cells stained: these were never seen in sheets (fig 4c). In the two examples where such tumours coexisted with transitional cell carcinoma (both grade 3) more extensive labelling was obtained (fig 4d). Better differentiated types of squamous cell carcinoma, including the verrucous type, did not stain. With MAK 6, more consistent positivity was observed both in the well and poorly differentiated squamous cell carcinoma (fig 4b), although its extent did not match that obtained with PK 63 and 121.

SPINDLE CELL COMPONENTS OF SQUAMOUS AND TRANSITIONAL CARCINOMAS

These were labelled by CAM 5·2, NCL5D3, and MAK 6 to varying degrees, but more intense staining was seen with polyvalent antikeratin serum (fig 5 ).

LYMPH NODE METASTASES

These maintained the staining profiles of their primary tumours.

\section{Discussion}

The selective patterns of expression of cytokeratin proteins in simple and stratified epithelia are apparent with the use of monoclonal antibodies against high and low molecular weight proteins. ${ }^{2471011}$ In adults, the simple epithelia are characterised by presence of low molecular weight $(40,45,52$ and $54 \mathrm{kd})$ proteins. The pattern for stratified epithelia in the urothelium is more complex and also includes proteins of higher molecular weights $(51,58 \text {, and } 59 \mathrm{kd})^{4579}$ : while the stratified squamous epithelium is characterised by the largest molecular weight proteins (up to $68 \mathrm{kd}$ ) with a lack of low molecular weight proteins. ${ }^{8923}$ It was reported that with neoplastic transformation, squamous cell carcinoma of certain sites aberrantly express low molecular weight cytokeratins which may therefore serve as discriminatory markers for malignancy. ${ }^{20}$

The application of these selective monoclonal antibodies as molecular probes has also shown differential distribution of cytokeratins in various layers of stratified epithelia in their native states which may be different in lesions derived from them ${ }^{247}$

Following the report by Bobrow et al that CAM 5.2, a monoclonal antibody against low molecular weight cytokeratins, identified changes associated with malignant transformation in squamous lesions of the uterine cervix ${ }^{20}$ we conducted a similar study on squamous lesions of the bladder infected with schistosomiasis. ${ }^{19}$ Our results showed that CAM $5 \cdot 2$ labelled only a minority of cells in the material. Intrigued by these findings we decided to extend the study by adding a wide range of lesions including hyperplastic and malignant urothelial ones. Lesions with and without schistosomiasis and of bladder and renal pelvis were studied to note any differences in results. Our panel of monoclonal antibodies was selected to localise low (CAM 5.2, NCL5D3), high 


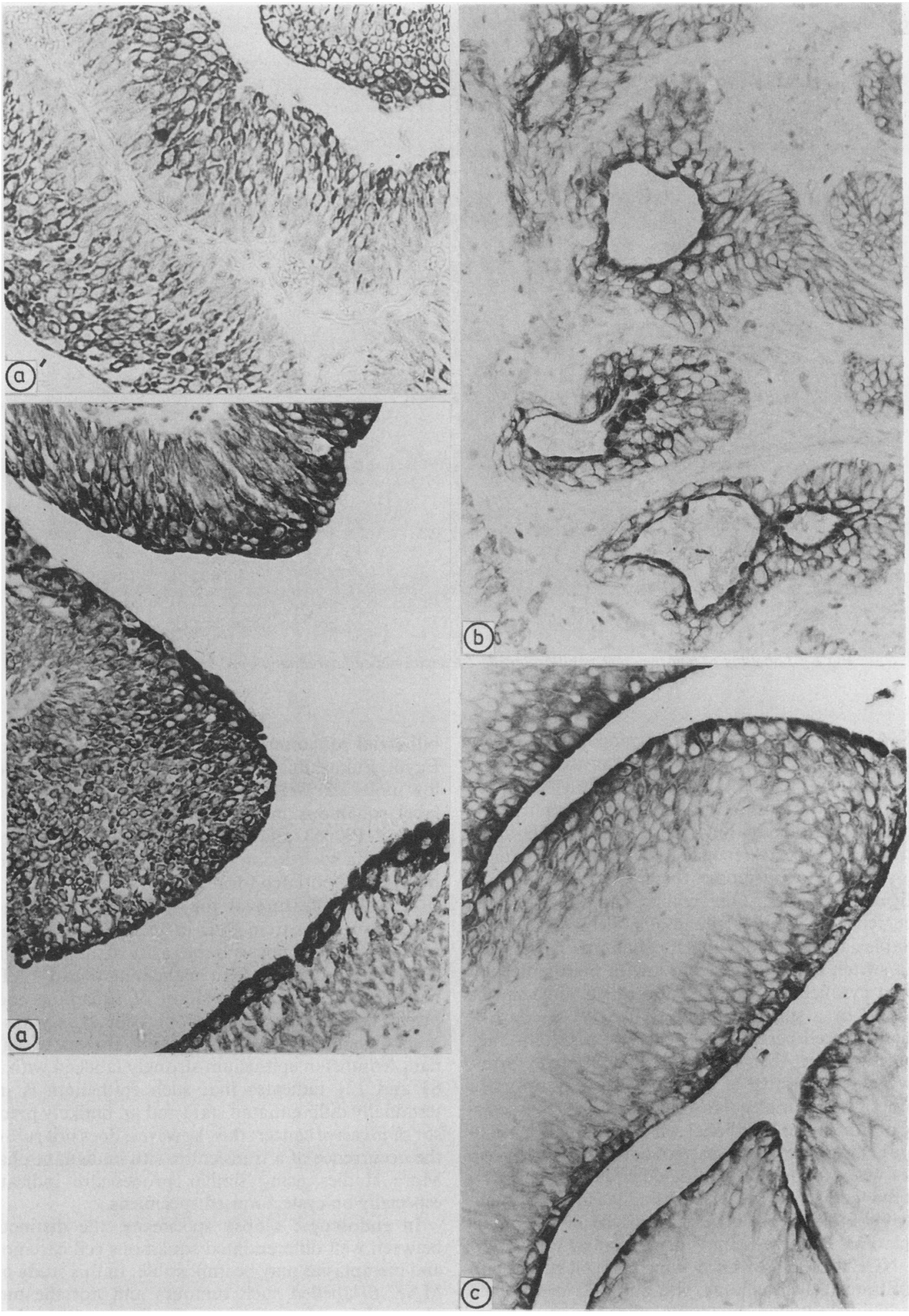

Fig 1 Peroxidase stain using CAM $5 \cdot 2$ and NCLSD3 on various transitional epithelial lesions. (a) Grade 2 papillary carcinoma (centre) contrasted with adjacent normal urothelium (below) and carcinoma in situ (above) (CAM 5.2); $\left(a^{\prime}\right)$ details of "gradient pattern" in a papillary process (CAM 5.2). (b) Hyperplastic cystic Brunn's nests (NCL5D3). (c) Grade 1 papillary transitional cell carcinoma (CAM 5.2). 


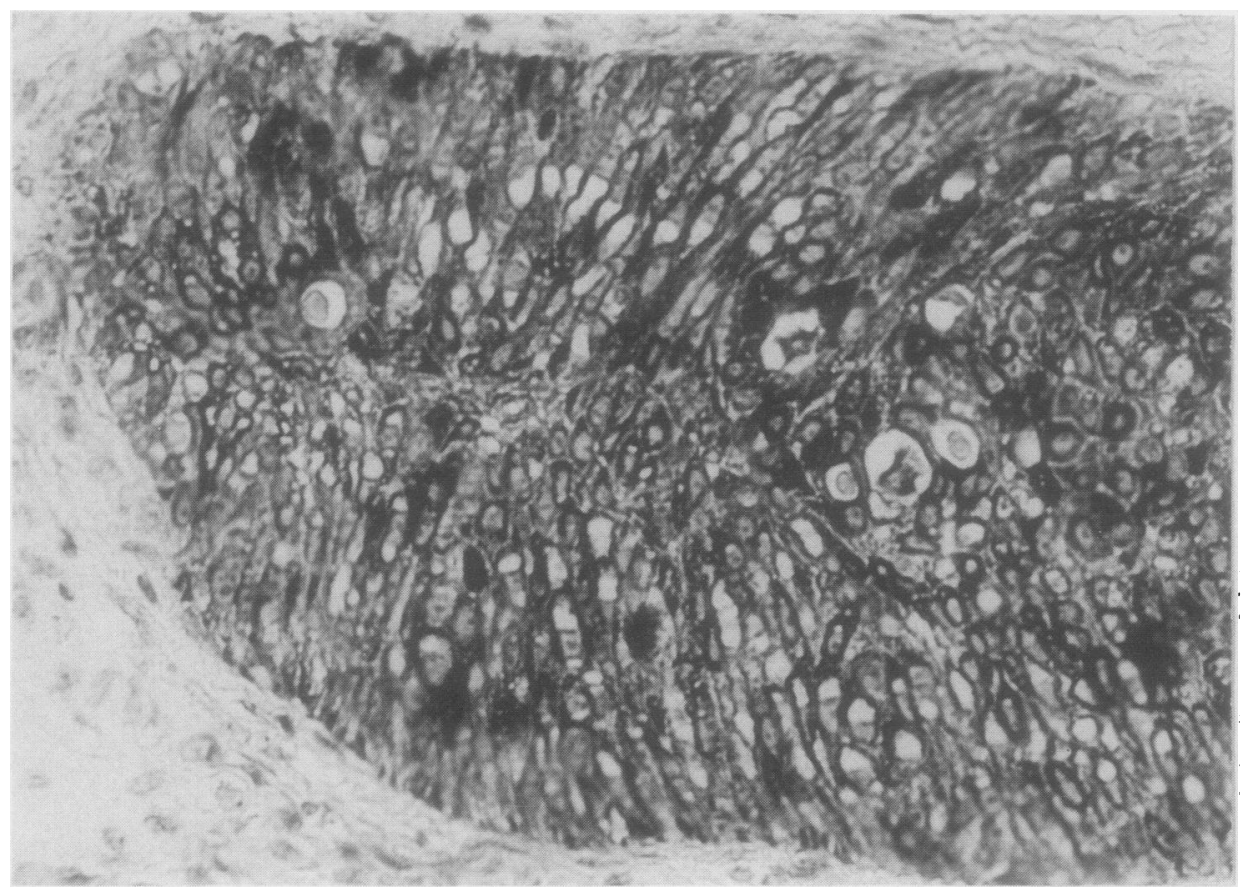

Fig 2 Labelling of invasive, non-papillary grade 2 transitional cell carcinoma by CAM $5 \cdot 2$ (APAAP).

(PK 63 and 121), and a broad range (MAK 6) of cytokeratin proteins. Polyvalent antikeratin was included for its reactivity against all epithelia.

As one of the aims of this study was to confirm and extend our earlier findings we used NCL5D3 as an additional probe to recognise low molecular weight cytokeratins to overcome the possible masking of antigenic epitopes. Our results indicate that the occurrence of benign squamous metaplasia or as metaplasia in transitional cell carcinoma is signalled by a switch in synthesis from low to high molecular weight cytokeratin proteins, and this change can be detected by a suitable antibody like PK 63 or 121 . Squamous cell carcinomas generally maintain such expression. In their poorly differentiated forms, however, a minority of tumour cells may revert to synthesis of low molecular weight proteins, characteristic of transitional epithelial cells. There is evidence of more extensive reversion pattern of this type in the two cases where poorly differentiated squamous cell carcinoma coexisted with transitional cell carcinoma, possibly indicating a different subtype of squamous carcinoma. Positive staining of large areas with CAM $5 \cdot 2$, NCL5D3, and MAK 6, which is typically seen in transitional cell carcinoma, was not a feature of even poorly differentiated squamous cell carcinoma.

Using a different set of antibodies on cases of bilharzial squamous cell carcinoma of bladder from Egypt, Fukushima et al have shown a total absence of low molecular weight cytokeratins but were unable to label squamous metaplasias and carcinomas selectively. ${ }^{24}$ PK 63 and 121 are therefore of value in identifying such lesions, especially the latter in their poorly differentiated forms.

A striking feature of the spectrum of squamous metaplasias to carcinomas in urinary tract with or without schistosomiasis is the rarity of morphological descriptions of an in situ malignant phase. ${ }^{172}$ This may lead to the interpretation of squamous metaplasias with minor degrees of cellular atypias as premalignant lesions. The invariable absence of malignant features in epithelium strongly labelled with PK 63 and 121 indicates that such epithelium is in a terminally differentiated state and an unlikely precursor of invasive cancer: this, however, does not rule out the occurrence of a transient in situ malignant phase. More studies using similar probes are indicated, especially on cystectomised specimens.

In endoscopic biopsy specimens, the distinction between well differentiated squamous cell carcinoma and metaplasias may be impossible. In this study only MAK 6 labelled such tumours and not the metaplasias, but only a minority of cells were stained; this antibody also consistently labelled groups of cells in 

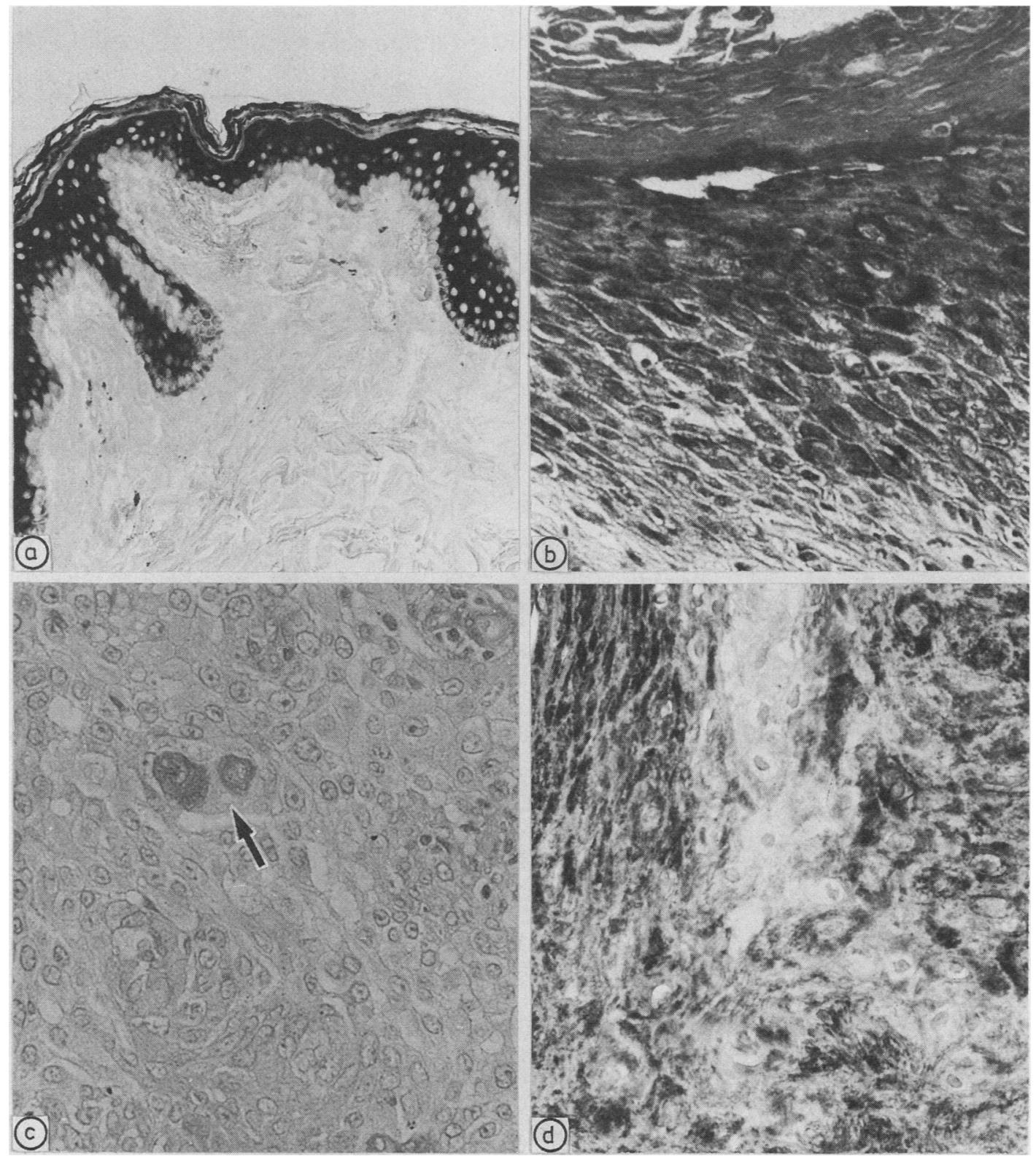

Fig 3 (a) Labelling with PK 63 and 121 of control epidermis; (b) pure squamous metaplasia with schistosomiasis; (c) focus of squamous metaplasia (arrow) in a transitional cell carcinoma; (d) and verrucous carcinoma. $((a)$ and $(c)$ peroxidase, $(b)$ and $(d) A P A A P)$.

squamous cancers of moderate to poor differentiation. This is probably related to its reactivity against a range of low and intermediate molecular weight cytokeratins. ${ }^{11}$

In evaluating the range of transitional epithelial lesions, the decoration patterns obtained with CAM 5.2, NCL5D3, and MAK 6 have important implications. Thus the bewildering variety of hyperplastic urothelial lesions associated with schistosomiasis, commonly seen in endoscopic biopsy specimens, may 

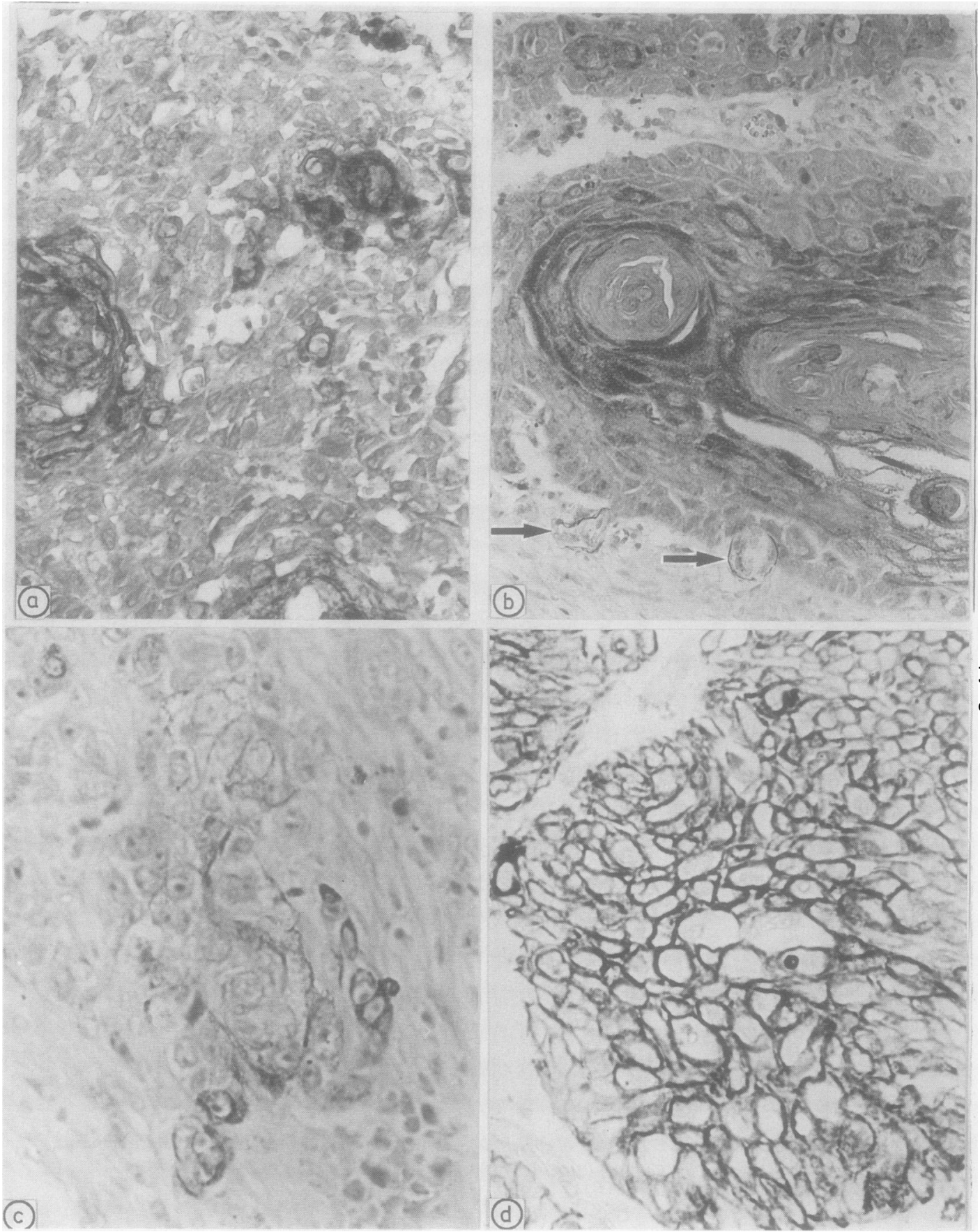

Fig 4 Decoration of squamous cell carcinomas by different antibodies. Moderately differentiated ones labelled with $P K 63$ and 121 in (a) and by MAK 6 in (b). Note schistosomal ova arrowed in (b). Labelling with CAM $5 \cdot 2$ of $a$ poorly differentiated tumour $(c)$, and of a similar tumour coexisting with a grade 3 transitional cell carcinoma $(d)$. (a peroxidase, $b, c$, and $d A P A A P$ ). 


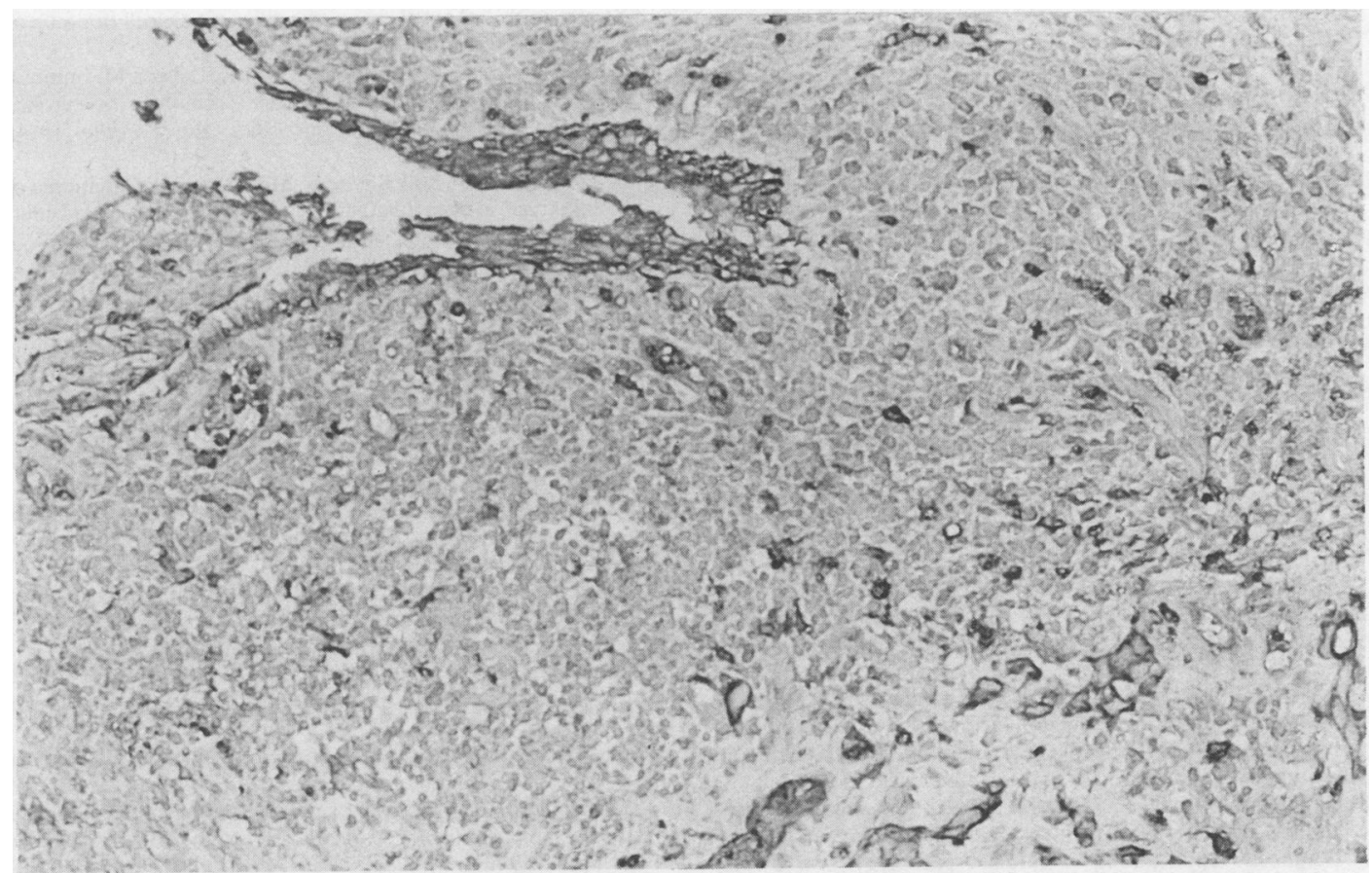

Fig 5 Spindle cell areas in a poorly differentiated squamous cell carcinoma. (Polyvalent antikeratin, peroxidase.)

be difficult to distinguish from parts of invasive solid tumours. The "gradient pattern" of staining as illustrated in fig $1 \mathrm{~b}$ may help in their identification. This pattern is also seen in grade 1 papillary transitional cell carcinoma and in papillary components of grade two tumours.

Among grade 2 tumours, the predominantly diffuse labelling of the non-papillary areas compared with the gradient pattern of the papillae obtained by this panel of antibodies may indicate a possible heterogeneity among these urothethial tumours. This may be a reflection of the widely different biological behaviours encountered within this group. This has been shown by using other variables such as expression of $\mathrm{ABH}$ and $\mathrm{T}$ antigens, ${ }^{25}$ nuclear ploidy, and survival. ${ }^{26}$

Our findings also lend indirect support to the view that carcinoma in situ of the flat urothelium and the non-invasive papillary carcinomas represent different pathways of oncogenesis in the urothelium..$^{27}$ Whether these inferences are valid for squamous carcinomas of the urinary tract requires further elucidation.

One application of the immunohistochemical demonstration of cytokeratin in endoscopic biopsy specimens is in cases of inflamed and ulcerated bladder tumour in which the spindle or dissociated cell component may be missed or its invasion inadequately assessed. The spindle cell components of the carcinomas we studied maintained their epithelial profiles unlike carcinomas of other sites such as the breast. ${ }^{15}$ The use of a polyvalent antikeratin agent, however, is adequate for this purpose. This study has also confirmed that cytokeratin profiles of these tumours in their nodal metastases is retained.

In conclusion, this study has shown that the use of a panel of suitably selected antibodies against cytokeratins may aid in the histopathological diagnosis of bladder tumours. Furthermore, it should be possible to investigate some of the unanswered questions regarding the importance of squamous metaplasias and the occurrence of in situ malignancy in relation to squamous carcinomas of the urinary tract. In this area the use of antibodies to high molecular weight cytokeratins may permit precise mapping of the regions of squamous metaplasia.

We thank Miss Masooma Naqvi and Mrs Helena Turley for their technical help and Mr Muhammad Siddique for his assistance in illustrating this paper.

This work was supported by Kuwait University Grant No: MG 018.

\section{References}

1 Osborn $M$, Weber $\mathrm{K}$. Tumor diagnosis by intermediate filament typing: a novel tool for surgical pathology. Lab Invest 1983;48:372-94. 
2 Quinlan RA, Schiller DL, Hatzfeld M, et al. Patterns of expression and organisation of cytokeratin intermediate filaments. Ann N Y Acad Sci 1985; 455:282-306.

3 Moll R, Franke WW, Schiller DL, Geiger B, Krepler R. The catalog of human cytokeratins: patterns of expression in normal epithelia, tumors and cultured cells. Cell 1982;31:11-24.

4 Moll R, Krepler R, Franke WW. Complex cytokeratin patterns observed in certain human carcinomas. Differentiation 1983;23:256-69.

5 Ramaekers FCS, Huysmans A, Moesker O, Schaart G, Herman C, Vooijs $P$. Cytokeratin expression during neoplastic progression of human transitional cell carcinomas as detected by a monoclonal and a polyclonal antibody. Lab Invest 1985;52: 31-8.

6 Summerhayes IC, Chen LB. Localisation of a Mr 52,000 keratin in basal epithelial cells of the mouse bladder and expression throughout neoplastic progression. Cancer Res 1982;42: 4098-109.

7 Achtstatter T, Moll R, Moore B, Franke WW. Cytokeratin polypeptide protein patterns of different epithelia of the human male urogenital tract: immunofluorescence and gel electrophoretic studies. J Histochem Cytochem 1985;33:415-26.

8 Sun T, Tseng SCG, Huang AJW, et al. Monoclonal antibody studies of mammalian epithelial keratins. A review. Ann N $Y$ Acad Sci 1985;455:307-29.

9 Huszar M, Gigi-Leitner O, Moll R, Franke WW, Geiger B. Monoclonal antibodies to various acidic (type I) cytokeratins of stratified epithelia-selective markers for stratification and squamous cell carcinomas. Differentiation 1986;31:141-53.

10 Shah KD, Tabibzadeh SS, Gerber MA. Comparison of cytokeratin expression in primary and metastatic carcinomas. Diagnostic applications in surgical pathology. Am J Clin Pathol 1987;87:708-15.

11 Listrom MB, Dalton LW. Comparison of keratin monoclonal antibodies MAK 6, AE1 : AE3 and CAM 5·2. Am J Clin Pathol 1987;88:297-301.

12 Ramaekers FCS, Haag D, Kant A, Moesker O, Jap PHK, Vooijs $P$. Coexpression of keratin and vimentin type intermediate filaments in human metastatic carcinoma cells. Proc Natl Acad Sci USA 1983;80:2618-22.

13 Gatter KC, Dunnil MS, Van Muijen GN, Mason DY. Human lung tumours may coexpress different classes of intermediate filaments. J Clin Pathol 1986;39:950-4.

14 Leader M, Collins M, Patel J, Henry K. Vimentin: an evaluation of its role as a tumour marker. Histopathology 1987;11:63-72.

15 Ellis IO, Bell J, Ronan JE, Elston CW, Blamey RW. Immunocytochemical investigation of intermediate filament proteins and epithelial membrane antigen in spindle cell tumours of the breast. J Pathol 1988;154:157-65.

16 Debus E, Moll R, Franke WW, Weber K, Osborn M. Immunohistochemical distinction of human carcinomas by cytokeratin typing with monoclonal antibodies. Am J Pathol 1984;114: 121-30.

17 Khafagy MM, El-Bolkainy MN, Mansour MA. Carcinoma of the bilharzial urinary bladder. A study of the associated mucosal lesions in 86 cases. Cancer 1972;30:150-9.

18 El-Bolkainy MN, Mokhtar NM, Ghoneim MA, Hussein MH. Impact of schistosomiasis on the pathology of bladder carcinoma. Cancer 1981;48:2643-8.

19 Tungekar MF, Al-Adnani MS, Gatter KC. Schistosomiasisassociated squamous lesions of the bladder. Expression of low molecular weight cytokeratin proteins. Br J Urol 1987;60:423-7.

20 Bobrow LG, Makin CA, Law S, Bodmer WF. Expression of low molecular weight cytokeratin proteins in cervical neoplasia. $J$ Pathol 1986;148:135-40.

21 World Health Organisation. Histological typing of urinary bladder tumours. In: International histological classification of tumours. Geneva: WHO, 1973.

22 Gatter KC, Ralfkiaer E, Skinner J, et al. An immunohistochemical study of malignant melanoma and its differential diagnosis from cther malignant tumours. J Clin Pathol 1985;38:1353-7.

23 Makin CA, Bobrow LG, Bodmer WF. A monoclonal antibody to cytokeratin for use in routine histopathology. J Clin Pathol 1984;37:975-83.

24 Fukushima S, Ito N, El-Bolkainy MN, Tawfik HN, Tatemoto Y, Mori M. Immunohistochemical observations of keratins, involucrin and epithelial membrane antigen in urinary bladder carcinomas from patients infected with Schistosoma haematobium. Virchows Arch (Pathol Anat) 1987;411:103-15.

25 Summers JL, Coon JS, Ward RM, Falor WH, Miller AW Weinstein RS. Prognosis in carcinoma of the urinary bladder 8 based upon tissue blood group ABH and Thomsen-Friedenreich antigen status and karyotype of the initial tumor. Cancer Res 1983;43:934-9.

26 Blomjous CEM, Schipper NW, Baak JP, Van Galen EM, de Voogt HJ, Meyer CJLM. Retrospective study of prognostic importance of DNA flow cytometry of urinary bladder carcinoma. $J$ Clin Pathol 1988;41:21-5.

27 Koss LG. Mapping of the urinary bladder: its impact on the concepts of bladder cancer. Hum Pathol 1979;10:533-48.

Requests for reprints to: Dr M F Tungekar, Pathology Department, Faculty of Medicine, Kuwait University, PO Box: 24923, Safat, 13110, Kuwait. 